Kivilehto, M., \& Salmi, L. (2017). Assessing assessment: The Authorized Translator's Examination in Finland, Linguistica Antverpiensia, New Series: Themes in Translation Studies, 16, 57-70.

\title{
Assessing assessment: The Authorized Translator's Examination in Finland
}

\author{
Marja Kivilehto \\ University of Tampere, Finland \\ marja.kivilehto@uta.fi
}

\section{Leena Salmi}

University of Turku, Finland

leena.salmi@utu.fi

The system for authorizing translators to translate legally valid texts used in Finland was revised in 2008 from a test measuring language skills into an examination containing translation assignments. The examination consists of two translation assignments and a test of the examinees' knowledge of the professional practices of authorized translators (tested with multiple-choice questions). In the assessment of the translation products, a predefined two-dimensional assessment system is used in which translations are marked for both content and language quality. In this article, we discuss the assessment systems used in Finland, Sweden, Norway and Germany and present the results of a case study on the application of the scoring chart used in the Finnish examination.

\section{Introduction}

The systems of certifying or authorizing translators vary between countries ${ }^{1}$. The process used for this purpose can be defined in the following way:

[T]he process by which potential translators and interpreters demonstrate minimum standards of performance to warrant official or professional recognition of their ability to translate or interpret and to practise professionally (Hlavac, 2013, p. 32).

Certification is most often required for translators to produce a particular category of translations that Pym, Grin, Sfreddo and Chan (2012, p. 23) call "certified translations". These are documents that "may be required by any official institution, for whatever reason (academic enrolments, applications for visa, passports, etc.); the translator may be a 'sworn' or 'authorized' translator" (Pym et al. 2012, p. 23).

The production of certified translations constitutes a special field of translating in which the translated document is meant to have the same evidential weight as the original and it needs to represent the original document 'as is'. In this type of translating, texts are "explicitly marked as texts transferred from another culture" (Nord, 1997, p. 47) and documentary translation, rather than instrumental translation, is usually needed. Accuracy is essential, and the focus is on the source text (ST). The translation has to correspond as closely as possible to the original document because its target audience is usually an institutional reader, an authority that needs the translated document in order to make decisions related to the identity or status of the holder of the document. The translation has to enable the authority itself to judge the data rather than the translator making such judgments (Taibi \& Ozolins, 2016, pp. 91-92). Therefore, the equivalence of the content of the translation to the original is considered important and "the function is to produce a target text (TT) that reflects the source culture as closely as possible" (Salmi \& Penttilä, 2013, pp. 118-119).

The assessment of translations can be based on an error analysis or on a comparison of the translation against predefined criteria that describe either what the translation should be like or the translation skills it should demonstrate (Angelelli, 2009, pp. 40-41; Turner, Lai, \& Huang, 2010). Error analysis has been regarded as trustworthy, and this is why it is used in many certification 
examinations (cf. Hale et al., 2012, p. 58). Nevertheless, research shows that criterion-referenced assessment can be as trustworthy as that based on error analysis (Turner et al., 2010).

This article deals with the system of authorized translators in use in Finland, with some comparisons to systems used in Sweden, Norway and Germany (in particular the state of Bavaria). We pay special attention to authorization examinations and their form of assessment used in them. By means of a case study based on assessment data from the Finnish examination, we aim to determine how assessment works in this examination and to discuss changing it to make it more transparent and trustworthy.

\section{Comparison of systems: Finland, Sweden, Norway and Germany (Bavaria)}

\subsection{Finland}

In Finland, authorization gives the authorized translator the right to produce legally valid documents for situations in which they are needed as a decision-making tool, for instance by an authority or in a legal procedure. The minimum standards mentioned by Hlavac (2013) cited above can either be demonstrated in an examination or based on a degree in translation. The system currently in force in Finland results from a reform in 2008, introduced to reflect better the work of these translators. A system used for this purpose has been in force since 1967. It was reformed once in 1989, and both reforms have brought a change in the terminology applied to authorized practitioners, from the original 'sworn translator' in 1967 to 'official translator' in 1989 and 'authorized translator' in 2008 (for details on the differences between the systems, see Salmi, 2017). The Finnish system is explained in more detail in Salmi and Penttilä (2013).

The Finnish National Board of Education ${ }^{2}$ grants authorized translator status to an individual after they pass the Authorized Translator's Examination or, alternatively, obtain a master's degree in translation. The system is centrally managed to guarantee uniformity, impartiality and equality for the examinees. The possibility of becoming authorized on the strength of a university degree in translation applies only to those language pairs taught in translator training programmes in Finland.

Candidates who wish to take the examination do not have to fulfil any requirements regarding their educational background. The examination can also be taken in languages in which no university-level education is available. It is offered once a year and consists of three parts:

1. multiple-choice questions on the professional practice of authorized translators;

2. one translation assignment in the field of law and administration;

3. one translation assignment in another specialist field that is chosen by the examinee (either business and economics, medicine, technology or education).

Part 1 takes 45 minutes to complete and parts 2 and 3 take 2 hours 45 minutes each. Computers are available throughout the examination, and the Internet and other reference materials can be used during the translation assignments. However, the use of translation memories, machine translation and email is not allowed, as is contacting other people during the examination (FNBE, 2016a).

\subsection{Sweden}

In Sweden, the Authorized Translator's Examination is offered by Kammarkollegiet (2016), a state agency responsible for legal, financial and administrative services. The examination takes place once a year and consists of three translation assignments. One of the assignments is a general language text and the other two are texts in specialist fields (law and economics). The examination begins with the law text ( 3 hours) and then proceeds to the general language text and the economics text (5 hours for both). Computers may be used and all kinds of reference materials are allowed. However, neither the use of the Internet nor contacting other people is permitted (Kammarkollegiet, 2016). 


\subsection{Norway}

In Norway, the Authorized Translator's Examination (statsautorisert translatør) is offered by NHH, the Norwegian School of Economics in Bergen (NHH, 2016a) and supervised by the Ministry of Education and Research. The examination is staged once a year and consists of two parts. The first part is an at-home examination that takes place in the autumn and the second is an on-site examination in the following spring. In the at-home component, the examinee translates a general language text and writes a reflective essay commenting on some particular challenges during the translation process and on their final solutions. In addition, they have to list the references they used. The examinee receives the text to be translated via email and then has five days to complete the tasks. These tasks must be adequately accomplished in order for the examinee to be able to take part in the on-site examination in the spring. In the on-site component, the examinee translates three LSP texts that cover the domains of economics/administration, law and technology. The examinee has seven hours in which to translate the three texts. Computers may be used and all kinds of reference materials, including the Internet, have been allowed since 2016. However, the use of translation memories and contacting other people are prohibited (NHH, 2016a, 2016b).

\subsection{Germany (Bavaria)}

In the State of Bavaria in Germany, the translator and interpreter examination (die Staatliche Prüfung) is administrated by the State Ministry of Education in Bavaria, Bayerisches Staatsministerium für Bildung und Kultur, Wissenschaft und Kunst. According to the examination regulations, the examination consists of five written assignments. First, the examinee writes an essay on the culture and society of the language to be examined ( 3 hours). Then they have four translation assignments, two of which consist of translations into the examinee's native language and two into the examinee's foreign language $(4 \times 90$ minutes). Two of the translation assignments are general language texts and two are LSP texts. The specialist fields for the examinee to choose from are economics, law, technology, natural sciences, humanities and social sciences. The assignments are written by hand and no reference materials are allowed unless otherwise explicitly stated (ÜDPO, 2016).

\section{Assessment in the Authorized Translator's Examination}

In this section, we concentrate on the assessment system for authorizing translators in Finland as compared to the systems in use in Sweden, Norway and Bavaria. Since this is the focus of the article, we do not discuss translation assessment in general (for translation assessment, see Colina, 2011, 2013; Gouadec, 2010; House, 2015).

Table 1 presents an overview of the assessment systems and the qualifications of the assessors: 
Table 1: Assessment in the Authorized Translator's Examinations in Finland, Sweden, Norway and Bavaria.

\begin{tabular}{|l|l|l|l|l|}
\hline & Finland & Sweden & Norway & Bavaria \\
\hline $\begin{array}{l}\text { Assessment } \\
\text { system }\end{array}$ & $\begin{array}{l}\text { Error analysis } \\
15 \text { error types } \\
\text { Error rating }\end{array}$ & $\begin{array}{l}\text { Error analysis } \\
14 \text { error types } \\
\text { No error rating }\end{array}$ & $\begin{array}{l}\text { Error analysis } \\
13 \text { error types } \\
\text { Error rating }\end{array}$ & $\begin{array}{l}\text { Criterion-based } \\
\text { analysis } \\
3 \text { criteria } \\
\text { Evaluation of the } \\
\text { criteria on a scale of } \\
1 \text { to } 6\end{array}$ \\
\hline $\begin{array}{l}\text { Assessor } \\
\text { qualifications }\end{array}$ & $\begin{array}{l}\text { Master's degree } \\
\text { Native-speakers of the } \\
\text { languages to be } \\
\text { examined } \\
\text { Assessor training }\end{array}$ & $\begin{array}{l}\text { Language professors } \\
\text { and language experts } \\
\text { Native-speakers of the } \\
\text { languages to be } \\
\text { examined }\end{array}$ & $\begin{array}{l}\text { Bilingual experts of } \\
\text { the languages to be } \\
\text { examined }\end{array}$ & $\begin{array}{l}\text { University teachers } \\
\text { and/or professional } \\
\text { translators } \\
\text { Native-speakers of } \\
\text { the languages to be } \\
\text { examined }\end{array}$ \\
\hline
\end{tabular}

As Table 1 shows, three of the four systems compared here use error analysis. Although error-based marking systems are becoming less frequently used (Hale et al., 2012, p. 64), they can be considered useful in examination and status-granting contexts. There, according to Brunette (2000, pp. 171173), the quality of a translated text is evaluated after the fact in order to determine admittance to, for example, professional associations. The translation is assessed using a grid and by determining errors and their severity (Brunette, 2000, p. 171). Certification to translate legally valid documents is an example of such a case.

In addition to the systems described here, error-based systems are used, for example those in Canada and the United States. In the translator certification tests of the Canadian Translators, Terminologists and Interpreters Council (CTTIC) errors are marked as those of translation or language (CTTIC, 2016) and the certification examinations of the American Translators Association (ATA) use a combination of error- and criterion-based assessment (ATA, 2016; Koby \& Champe, 2013). Error-based evaluation also seems to be a widely used and preferred method within the translation industry (O'Brien, 2012, p. 74) - according to TAUS (2016), a "vast majority of the providers and buyers of translation services manage their quality program with an error typology template" (p. 5). Recent initiatives have been carried out to harmonize the error classifications used within the industry (Lommel et al., 2015; TAUS, 2016).

\subsection{Finland}

In the Finnish Authorized Translator's Examination, both language and translation skills are examined using two translation assignments. The examination is meant to sift out those translators capable of producing legally valid translations (FNBE, 2016b). The assignments are assessed by two assessors, one of whom is an expert in the source language (SL) and the other in the target language (TL). Assessment is performed in accordance with the assessment criteria for language and translation skills (FNBE, 2012, p. 8). The assessors perform the assessments individually, but not totally independently. They must discuss their individual assessments and come to a shared conclusion. If they cannot agree, a third assessor is usually involved. To ensure that examination is assessed fairly, it is important that the assessment is as transparent and consistent as possible and that the examinees are informed how the assessment system has been applied to their translations (FNBE, 2015, pp. 4-5). It is not possible for an examinee to appeal to a higher body if they are dissatisfied with the result of an assessment, but a person failing the examination has the right to request the Authorized Translators' Examination Board (FNBE, 2012, p. 9) to reassess their translations. 
The translation assessments are based on an error analysis: the assessors apply a scoring chart (see Appendix) ${ }^{3}$ in which errors are categorized as those of equivalence of content ( $\mathrm{C}$ errors) and as those of acceptability and readability (A errors). In other words, in the first category there are instances where the meaning of the ST has not been transferred into the translation, and in the second there are problems in the TL (style, register, grammar, punctuation, etc.). Error points vary from 1 to 9 , depending on the severity of the errors. One nine-point error alone is enough to fail a translation. However, the function of the translation, its degree of difficulty and the time the examinee has at their disposal are taken into account in the final assessment (FNBE, 2015, pp. 4-5). The handbook for assessors does not give specific guidelines on what is considered a 2-point or a 4point error, but assessment is regularly discussed during the seminars organized three times a year for those involved in the system (one seminar on the selection of examination texts and two on the assessment).

As mentioned above, the examinees are informed how the assessment system has been applied to their translations (FNBE, 2015, pp. 4-5) and, in practice, they receive a copy of the marked translations (FNBE, 2016a). Marking errors is therefore a practical way of identifying the problems found in the translations. As Salmi and Kinnunen (2015, p. 235) point out, this also helps those who fail to identify their weak points.

Assessors must hold a master's degree at least and have a sound knowledge of translating pragmatic texts and translating in the examination languages. Under special circumstances, the master's degree can be replaced by a bachelor's degree if the person is a native-speaker of the examination language to be assessed (the TL). In addition to the criteria above, assessors must have completed assessor training approved by the Finnish National Board of Education (A 1232/2007, Section 12). They are entered into the assessor register for five years, renewable upon application, provided that they continue to fulfil the eligibility criteria and have been maintaining their assessment skills in practice (L 1231/2007, Section 14).

\subsection{Sweden, Norway and Bavaria}

The Authorized Translator's Examinations in Sweden, Norway and Bavaria are characterized by both similarities and differences when they are compared to the Finnish examination. In Finland, Sweden and Norway, the assessment of the translations is based on an error analysis, whereas in Bavaria the assessment is criterion-based. The qualifications of the assessors also display both similarities and differences: in Finland, Sweden and Bavaria, the assessors are usually university teachers and translators; in Sweden, the translation direction determines which qualifications are needed.

In what follows, we discuss the assessment procedures in the Swedish, Norwegian and Bavarian systems in detail.

As already mentioned, in Sweden the Authorized Translator's Examination is offered by Kammarkollegiet. The assessment is based on an error analysis. Fourteen error types are categorized as "severe" (eight) and "other" (six) errors. "Severe" errors mostly include content errors, but even idiomatic errors can be considered "severe". "Other" errors are those concerning a wrong shade of meaning, style and spelling (Kammarkollegiet, 2013). In Sweden, no error points are given. Instead, the two main categories - severe and other - serve as a reference point for the assessors. In principle, only one error is sufficient to fail the examination, but if the translation is otherwise good, assessors consider the kind of error it is and how it affects the content of the translation. On the whole, the type of error plays a significant role when assessing translations, and the general impression, not the number of errors, is decisive (P. Ehrnebo, personal communication, 3 August 2016). When assessing examinees' translations, assessors pay attention to precision, idiomatic language and style (Kammarkollegiet, 2016).

As mentioned above, in Norway, the Authorized Translator's Examination is organized by $\mathrm{NHH}$, the Norwegian School of Economics. Similarly to Sweden, the assessment is based on an error analysis. There are 13 error types in the examination: six 'severe' and seven 'other' errors. "Severe" errors include translation solutions that do not comply with the translation brief as well as 
translation solutions such as unjustified omissions or misinterpretation of the message. The use of inadequate words that distort the intended meaning and the non-application of genre conventions are also considered "severe. "Other" errors concern the wrong shade of meaning, inadequate style or misspelling (NHH, 2016a). In Norway, no error points are given. Instead, the two main categories "severe" and "other" - serve as a reference point for the assessors. Overall, it is impossible to say how many "severe" errors a translation may contain but still be accepted. Usually there is more than one "severe" error combined with several "other" errors. Systematic repetition of "other" errors is categorized as a "severe" error (NHH, 2016a; I. Simonnæs, personal communication, 1 December 2016).

In Bavaria, the Authorized Translator's Examination (die Staatliche Prüfung) is more a general translation examination than an examination qualifying translators to translate legally valid texts. Assessment is criterion-based (use of descriptors), taking three criteria into account: (1) content correctness and equivalence, (2) vocabulary/terminology and expression and (3) language correctness. When assessing content correctness and equivalence, assessors pay attention to text comprehensibility, logic and possible omissions, whereas the criterion of vocabulary/terminology and expression means that assessors take note of how LSP terms, style and register are translated. As to language correctness, attention is paid to sentence structure, spelling and punctuation. The three assessment criteria are evaluated on a scale of 1 to 6 , where 1 is an excellent performance and 6 a performance that does not fulfil the requirements. To pass the examination, the examinee must get an average mark of 4 (V. Weisel, personal communication, 27 July 2016).

In recruiting assessors, the Swedish Kammarkollegiet looks primarily for professors in the languages to be examined (L. Kraft, personal communication, 3 October 2016). Other language experts are also engaged, as the assessment procedures in Sweden vary depending on the translation direction. Translations from Swedish to other languages are assessed by two assessors, one of whom has the SL and the other the TL as a native language. Translations from other languages to Swedish are first assessed by a Swedish-speaking language consultant. If the language consultant thinks that the Swedish language is acceptable, the translation is passed on to an SL expert. Of the three translations the examinees do, the general language translation is assessed first. If it is deemed unacceptable, the assessment process ends. If the translation is acceptable, the assessors assess the other translations and discuss them. There may be small differences in the way the assessors do so, but overall they have to agree on the quality of the translations. If the assessors do not come to a shared conclusion, a third assessor can be brought in (P. Ehrnebo, personal communication, 3 August 2016).

In Norway, the assessors are chosen on the basis of various criteria agreed upon by the steering committee for the Authorized Translator's Examination. Usually they are bilingual experts of the languages to be examined and have relevant experience in various kinds of translation task. If possible, one of the two assessors is a native-speaker of the SL and the other that of the TL. The two assessors assess separately, but discuss the assessments afterwards. If they disagree, a third assessor is brought in. Examinees have the right to appeal the assessment, in which case a new assessment is then performed by two new assessors who have no information whatsoever about the previous assessment. Their assessment is final (I. Simonnæs, personal communication, 25 August 2016; I. Simonnæs, personal communication, 1 December 2016).

In Bavaria, the qualifications of the assessors vary: they may be either university teachers and/or professional translators. One of the two assessors is usually a native-speaker of the TL and the other is a subject expert. Assessors assess the translations separately, but discuss their assessments if there are disagreements. If the assessors cannot come to an agreed conclusion, a third assessor can be involved. Examinees have the right to see their assessed translations and also to appeal an assessment. If the appeal is justified, the assessors may have to make a new assessment (V. Weisel, personal communication, 27 July 2016). 


\section{Assessment in the Finnish Authorized Translator's Examination in 2012-2014}

In this section, we present a case study conducted to see how the scoring chart is applied in practice in the Finnish system. We analysed a sample of translations from the examinations taken in 2012$2014^{4}$. The data analysed here consist of translations from nine examinees in the English-Finnish language pair and from 19 in the Finnish-English pair (hereafter referred to as 'the English set'), as well as from seven examinees in the language pair Swedish-Finnish and from 17 in the pair FinnishSwedish ('the Swedish set'); altogether 52 examinees. Since each examinee produces two translations, there are 56 translations in the English set and 48 in the Swedish set. And because each translation is assessed by two assessors, the data includes 112 assessments in the English set and 96 in the Swedish set. Table 2 presents the number of translations analysed:

Table 2: Number of translations analysed, by language pair.

\begin{tabular}{|c|c|c|c|c|c|}
\hline & Examinees & Translations & Translations & \multicolumn{2}{|c|}{ Total } \\
\hline English-Finnish & 9 & 18 & 36 & \multirow{2}{*}{56} & \multirow{2}{*}{112} \\
\hline Finnish-English & 19 & 38 & 76 & & \\
\hline Swedish-Finnish & 7 & 14 & 28 & \multirow{2}{*}{48} & \multirow{2}{*}{96} \\
\hline Finnish-Swedish & 17 & 34 & 68 & & \\
\hline
\end{tabular}

In the following sections, we analyse the assessments by error type.

\subsection{English-Finnish-English}

This section deals with the assessors' assessments of the translations from English into Finnish (18 translations) and from Finnish into English (38 translations). Four different assessors were involved. Table 3 shows how the errors marked are divided into the different error types.

Table 3: Error types marked in the English set.

\begin{tabular}{|l|c|c|c|c|}
\hline Type & \multicolumn{2}{|c|}{ ENG-FIN } & \multicolumn{2}{c|}{ FIN-ENG } \\
\hline & Number & $\%$ & Number & $\%$ \\
\hline C1 & 37 & 7.7 & 12 & 0.6 \\
\hline C2 & 23 & 4.8 & 15 & 0.8 \\
\hline C3 & - & 0.0 & - & 0.0 \\
\hline C4 & 1 & 0.2 & 2 & 0.1 \\
\hline C5 & 11 & 2.3 & 33 & 1.7 \\
\hline C6 & 30 & 6.3 & 7 & 0.4 \\
\hline C7 & 196 & 40.9 & 779 & 41.2 \\
\hline C8 & 3 & 0.6 & 1 & 0.1 \\
\hline A1 & 15 & 3.1 & 89 & 4.7 \\
\hline A2 & 4 & 0.8 & 16 & 0.8 \\
\hline A3 & 1 & 0.2 & 11 & 0.6 \\
\hline A4 & 4 & 0.8 & 79 & 4.2 \\
\hline A5 & 56 & 11.7 & 560 & 29.6 \\
\hline A6 & 36 & 7.5 & 84 & 4.4 \\
\hline A7 & 62 & 12.9 & 204 & 10.8 \\
\hline TOTAL & 479 & & 1,892 & \\
\hline
\end{tabular}

As can be seen from Table 3, the English-Finnish translations contained 479 errors in total, and the Finnish-English 1,892. The most common error type was C7, "an individual word/term that is imprecise, unsuitable or irrelevant or an omission or an addition not essentially affecting the meaning of the text". This type accounted for 40.9 per cent of the errors into Finnish and 41.2 per cent of the errors into English. The next most common error types were acceptability errors, A7, "a 
spelling mistake that does not affect the meaning", into Finnish (12.9\%), and A5, "a structural error that does not cause misinterpretation", into English (29.6\%).

We illustrate the error types C7 and A5 with an example. Example (1) presents the ST in Finnish, with emphasis on the errors $\mathrm{C} 7$ and $\mathrm{A} 5$ added:

(1) Rikesakkomääräyksen saaneen henkilön tulee vastustaa saamaansa rikesakkomääräystä, jos hän kiistää syyllisyytensä määräyksessä tarkoitettuun rikokseen esim. siksi, että hän ei ole kuljettanut rikkomukseen käytettyä ajoneuvoa tai ei ole ajanut väitettyä ylinopeutta. (ST, underlining is our emphasis)

$=$ [The person having received a summary penal fee order should object to the order if he/she denies being guilty to the offence referred to in the order for the reason that, for example, he/she was not driving the vehicle used in the offence or he/she was not driving at the alleged illegal speed.]

Example (2) shows the translation by Examinee A, with emphasis (underlining) on the error C7 added:

(2) The person receiving the summary penal fee order must dispute the order if the person denies his or her participation in the intended crime for the reason that, for example, he or she was not driving the vehicle used in the offence or he or she was not driving at the alleged illegal speed.

In Example (2), the translation "the intended crime" for "määräyksessä tarkoitettuun rikokseen" contains two C7 errors: the Finnish "määräyksessä tarkoitettuun" should be rendered as "referred to in the order" as it refers to the offence mentioned in the penal fee order, not a crime intended by the person; and "rikos" should be rendered here by a more general term such as "offence" or "violation".

Example (3) shows the translation by Examinee B to illustrate an A5 error (emphasis (underlining) added):

(3) The recipient of a summary penal fee order should object to the issued summary penal fee order if he or she pleads not guilty of the charged crime f. ex. because he or she has not operated the vehicle used in the offence or has not been exceeding the speed limit as alleged.

In example (3), the verb form "has not been exceeding" should read "did not exceed" (error type A5).

An error type that did not occur at all in either direction was C3, described as "the translation function is disregarded, leading to an inadequate result". Other types that occurred rarely were C4, "unfounded alternative translation equivalents, i.e. the choice is left to the examiner", with 1 or 2 occurrences, and C8, "incomplete or erroneous equivalents for the cultural and social context of the source language", with 3 and 1 occurrences into Finnish and English respectively.

Otherwise, the rare error types differed according to the translation direction: A3, "a spelling mistake that affects the interpretation of the text section", occurred only once into Finnish $(0.2 \%)$, but had 11 occurrences $(0.6 \%)$ into English. This is understandable, given that Finnish is a phonetic language, compared to English, where the same pronunciation may have several different spellings.

\subsection{Swedish-Finnish-Swedish}

This section deals with the assessors' assessments of the translations from Swedish into Finnish (14 translations) and Finnish into Swedish (34 translations). Six assessors participated in this case. The composition of the group of assessors varied from one year to another, which naturally can have had an effect on the results.

Table 4 shows how the errors marked were divided into the different error types. 
Table 4: Error types used in the Swedish set.

\begin{tabular}{|l|c|c|c|c|}
\hline Type & \multicolumn{2}{|c|}{ SWE-FIN } & \multicolumn{2}{c|}{ FIN-SWE } \\
\hline & Number & $\%$ & Number & $\%$ \\
\hline C1 & 17 & 3.8 & 28 & 2.8 \\
\hline C2 & 27 & 6.0 & 42 & 4.3 \\
\hline C3 & - & 0.0 & 8 & 0.8 \\
\hline C4 & 1 & 0.2 & 4 & 0.4 \\
\hline C5 & 8 & 1.8 & 31 & 3.1 \\
\hline C6 & 15 & 3.3 & 16 & 1.6 \\
\hline C7 & 90 & 20.1 & 191 & 19.4 \\
\hline C8 & - & 0.0 & 24 & 2.4 \\
\hline A1 & 19 & 4.2 & 54 & 5.5 \\
\hline A2 & 38 & 8.5 & 73 & 7.4 \\
\hline A3 & 5 & 1.1 & 11 & 1.1 \\
\hline A4 & 12 & 2.7 & 72 & 7.3 \\
\hline A5 & 52 & 11.6 & 106 & 10.8 \\
\hline A6 & 109 & 24.3 & 215 & 21.8 \\
\hline A7 & 55 & 12.3 & 111 & 11.3 \\
\hline TOTAL & 448 & & 986 & \\
\hline
\end{tabular}

As can be seen from Table 4, the Swedish-Finnish translations contained 448 errors in total and the Finnish-Swedish 986. The most common error type, unlike in the English set, was A6, "individual style errors and unidiomatic expressions", with 24.3 per cent occurring in the translation into Finnish and 21.8 per cent in that into Swedish, but C7 came second, with 20.1 per cent into Finnish and 19.4 per cent into Swedish. The third most common error type was A7, which was ranked second for the English-Finnish translations and third in the Finnish-English translations (Table 2).

Error types that did not occur at all into Finnish were C3 ("leaving the translation function disregarded") and C8 ("incomplete or erroneous equivalents for the cultural and social context of the source language"), but, interestingly, there were eight occurrences of C3 (0.8\%) into Swedish and as many as 24 occurrences of C8 (2.4\%). These occurrences come from different assessors, so it is not a question of only one or two assessors identifying these error types.

One error type rarely identified in both directions was $\mathrm{C} 4$, "unfounded alternative translation equivalents, i.e. the choice is left to the examiner", with 1 and 4 occurrences into Finnish and Swedish respectively.

\subsection{English-Finnish-English and Swedish-Finnish-Swedish compared}

Table 5 shows a comparison between the error types that were identified by the assessors in the English and the Swedish sets. 
Table 5: Error types used in the English and Swedish sets compared.

\begin{tabular}{|l|c|c|c|c|}
\hline Type & ENG & $\%$ & SWE & $\%$ \\
\hline C1 & 49 & 2.1 & 45 & 3.1 \\
\hline C2 & 38 & 1.6 & 69 & 4.8 \\
\hline C3 & 0 & 0.0 & 8 & 0.6 \\
\hline C4 & 3 & 0.1 & 5 & 0.3 \\
\hline C5 & 44 & 1.9 & 39 & 2.7 \\
\hline C6 & 37 & 1.6 & 31 & 2.2 \\
\hline C7 & 975 & 41.1 & 281 & 19.6 \\
\hline C8 & 4 & 0.2 & 24 & 1.7 \\
\hline A1 & 104 & 4.4 & 73 & 5.1 \\
\hline A2 & 20 & 0.8 & 111 & 7.7 \\
\hline A3 & 12 & 0.5 & 16 & 1.1 \\
\hline A4 & 83 & 3.5 & 84 & 5.9 \\
\hline A5 & 616 & 26.0 & 158 & 11.0 \\
\hline A6 & 120 & 5.1 & 324 & 22.6 \\
\hline A7 & 266 & 11.2 & 166 & 11.6 \\
\hline Total & 2,371 & & 1,434 & \\
\hline
\end{tabular}

Table 5 shows that the most commonly occurring error types differ between the language sets: in the English set, the most commonly identified type is C7 ("wrong, omitted or added terminology", 41.1\%), but in the Swedish set it is A6 ("style errors and unidiomatic expressions", 22.6\%). C7 is second in the Swedish set and A5 ("structural error not causing misinterpretation") in the English set.

One reason for the "popularity" of error type C7 may be the fact that it contains, in fact, three separate error types: (1) an incorrect term, (2) an omission and (3) an addition. Another reason could be the fact that producing legally valid translations requires accuracy and precision, as the translation may be used as a tool for decision-making within an authority or in a legal procedure. A third reason is related to the second: all the text types translated are LSP texts that usually contain specific terminology and translators are expected to find and select the correct terminology.

When the percentages shown in Table 5 are totalled, we notice that the A errors are used more in the Swedish set (65\%) than the C errors (35\%); in the English set they are more equally divided (A $51 \%$, C 49\%). The lower number of content equivalence problems might be a result of better knowledge of the SL among the examinees in general (no comprehension problems) in the Swedish set. We have no information on the examinees' linguistic background, since the examinations are taken anonymously and such information is not even asked upon registration; but this factor might be a plausible reason in a bilingual country such as Finland. Therefore, this difference in the division between error types would reflect only the nature of the errors the examinees typically make in a language set.

\section{Conclusions}

In this article, we provided an overview of the assessment system in the Finnish Authorized Translator's Examination and discussed the assessment systems in the Swedish, Norwegian and Bavarian examinations. We also presented an analysis of the use of the assessment system in the Finnish examination in the language pairs English-Finnish-English and Swedish-Finnish-Swedish.

As our overview points out, the assessment systems applied in the Authorized Translator's Examinations in Finland, Sweden, Norway and Bavaria resemble one another. In each examination, two main categories - the equivalence of the ST and TT and the acceptability of the TTs - are taken into account. There are, however, differences in how these main categories are applied. In Finland, Sweden and Norway, error analysis is used, but not in Bavaria. Whereas in Finland errors are rated, this is not the case in Sweden or Norway. Errors are only categorized, although there is a severity rating contained within the categories. The Bavarian system differs from the Finnish, Swedish and 
Norwegian systems in that the assessors apply criterion-based assessment. Although error-based assessment may be criticized, it is perhaps considered as a more suitable choice for examinations that have a decisional aim (Brunette, 2000, pp. 171-172), and because in this type of translating, accuracy is essential, the focus is on the ST, and the translation needs to correspond as closely as possible to the original (Taibi \& Ozolins, 2016, pp. 91-92).

The analysis of the translation assignments in the Finnish examination provides grounds for rethinking the assessment. The analysis showed that not all of the error types are applied, and some of them, such as $\mathrm{C} 7$, are used very often. In fact, the problem with this particular error type has already been taken into account, as the scoring chart has, since 2014, been modified so that omission and addition have been left out of error type C7, and a separate type has been created for them ("an omission or an addition essentially affecting the meaning"). However, this does not remove the difficulty of selecting between error types and categories. Not all the errors can be categorized easily as $\mathrm{C}$ or $\mathrm{A}$ errors, not to mention placed in the various error types of the main categories. Therefore, it might be useful to move to a system based on "severe" and "other" errors in line with Sweden and Norway and to reduce the number of error types. In addition, replacing the error points from 1 to 9 with a severity scale that has two or three levels might make it easier for the assessors to decide on the severity of the errors.

Another option would be to move to criterion-based assessment, as has been done in Bavaria. However, as mentioned in section 3.1, the examinees in Finland receive a copy of their marked translations (FNBE, 2016a) and therefore errors need to be identified in the translations. As Salmi and Kinnunen (2015, p. 235) point out, this also helps to enlighten those who fail to see where their weak points are. In that sense, the Finnish examination does also have a didactic aim, although this is secondary. In any case, we plan to continue our research by proposing a simplified scoring chart and to test it with a sample of assessors and translations from the next Finnish examination.

\section{References}

A 1232/2007 = Valtioneuvoston asetus auktorisoiduista kääntäjistä [Government Decree on Authorised Translators]. (2016, August 9). Retrieved from http://www.finlex.fi/fi/laki/ajantasa/2007/20071232.

Angelelli, C. V. (2009). Using a rubric to assess translation ability: Defining the construct. In C. V. Angelelli \& H. E. Jacobson (Eds.), Testing and assessment in Translation and Interpreting Studies: A call for dialogue between research and practice (pp. 13-47). Amsterdam: John Benjamins.

ATA (2016). Certification exam overview. Retrieved from https://www.atanet.org/certification/aboutexams_ overview.php.

Brunette, L. (2000). Towards a terminology for translation quality assessment. The Translator, 6(2), 169-182. doi:10.1080/13556509.2000.10799064

Colina, S. (2011). Evaluation/Assessment. In Y. Gambier \& L. van Doorslaer (Eds.), Handbook of Translation Studies (pp. 43-48). Amsterdam: John Benjamins.

Colina, S. (2013). Assessment of translation. In C. A. Chapelle (Ed.), The encyclopedia of Applied Linguistics (pp. 17). Chichester: Wiley-Blackwell.

CTTIC (2016). CTTIC Standard Certification Translation Examination Marker's Guide. Retrieved from http://www.cttic.org/certification.asp

FNBE = Finnish National Board of Education. (2012). Qualification requirements for authorised translators' examinations 2012. Regulations and Guidelines 22/011/2012.

FNBE = Opetushallitus. (2015). Käsikirja 2015. Auktorisoidun kääntäjän tutkinto. Toimintaohjeet tutkintotehtävien arvioijalle [Finnish National Board of Education. Handbook 2015. Authorised Translator's Examination. Instructions for Assessors of Translation Assignments]. Helsinki: Opetushallitus.

FNBE = Opetushallitus. (2016a). Ohjeita tutkintoon 12.11.2016 osallistuvalle [Instructions to those participating in the examination on 12 November 2016]. (2016, October 14). Retrieved from http://www.oph.fi/koulutus_ja_ tutkinnot/auktorisoidut_kaantajat/tutkintoon_osallistuminen/tutkinnon_suorittamisesta

FNBE = Opetushallitus (2016b). Yleistä auktorisoidusta kääntämisestä [About authorised translating in general] Retrieved from http://oph.fi/koulutus_ja_tutkinnot/auktorisoidut_kaantajat/usein_kysyttya/yleista. 
Gouadec, D. (2010). Quality in translation. In Y. Gambier \& L. van Doorslaer (Eds.), Handbook of Translation Studies (pp. 270-275). Amsterdam: John Benjamins.

Hale, S. B., Garcia, I., Hlavac, J, Kim, M., Lai, M., Turner, B., \& Slatyer, H. (2012). Improvements to NAATI testing: Development of a conceptual overview for a new model for NAATI standards, testing and assessment. The National Accreditation Authority for Translators and Interpreters (NAATI). Retrieved from https://www.naati.com.au/projects/improvements-to-naati-testing-int/

Hlavac, J. (2013). A cross-national overview of translator and interpreter certification procedures. Translation \& Interpreting: The International Journal for Translation \& Interpreting Research, 5(2), 32-65.

House, J. (2015). Translation quality assessment: Past and present. London: Routledge.

Kammarkollegiet. (2013). Kort förklaring till feltyperna [A short explanation of error types]. (2016, August 8). Retrieved from http://www.kammarkollegiet.se/sites/default/files/Kort\%20f\%C3\%B6rklaring\%20till\%20fel typerna.pdf.

Kammarkollegiet. (2016). Auktorisationsprovet för översättare [Examination for authorised translator] (2016, August 8). Retrieved from http://www.kammarkollegiet.se/tolkar-och-oversattare/auktorisationsprovet-for-over sattare.

Koby, G. S., \& Champe, G. G. (2013). Welcome to the real world: Professional-level translator certification. Translation and Interpreting, 5(1), 156-173.

L 1231/2007 = Laki auktorisoiduista kääntäjistä [Act on Authorised Translators] (2016, August 9). Retrieved from http://www.finlex.fi/fi/laki/ajantasa/2007/20071231.

Lommel, A., Görög, A., Melby, A., Uszkoreit, H., Burchardt, A. and Popović, M. (2015). Harmonised metric. Project Report, QT21 project (funded by the European Union's Horizon 2020 program for ICT) Retrieved from https://www.taus.net/evaluate/dqf-tools\#error-typology.

Melby, A. K. (2013). Introduction. Translation \& Interpreting. The International Journal for Translation \& Interpreting Research 5(1), 1-12.

$\mathrm{NHH}=\mathrm{NHH}$ Norges Handelshøyskole. (2016a). Autorisasjonsprøve $i$ øversœettelse [Examination for Authorised Translator]. (2016, 28 November). Retrieved from https://www.nhh.no/institutt/fagsprak-og-interkulturellkommunikasjon/autorisasjonsprove-i-oversettelse/.

$\mathrm{NHH}=$ NHH Norges Handelshøyskole. (2016b). Forskrift for autorisasjonsprøve for å bli statsautorisert translatør (translatøreksamen) ved Norges Handelshøyskole [Regulations of the Examination for Stateauthorised Translator in the NHH Norwegian School of Economics]. (2016, November 28). Retrieved from https://www.nhh.no/institutt/fagsprak-og-interkulturell-kommunikasjon/autorisasjonsprove-ioversettelse/forskrift-for-autorisasjonsprove/.

Nord, C. (1997). Translating as a purposeful activity: Functionalist approaches explained. Manchester: St. Jerome.

O'Brien, S. (2012). Towards a dynamic quality evaluation model for translation. The Journal of Specialised Translation 17, 55-77.

Pym, A., Grin, F., Sfreddo, C., \& Chan, A. (2012). The status of the translation profession in the European Union. Studies on Translation and Multilingualism, DGT/2011/TST. Brussels: European Commission (2016, October 23). Retrieved from http://ec.europa.eu/dgs/translation/publications/studies/index_en.htm

Salmi, L. (2017). Tähänastisten suomalaisten kääntäjätutkintojen vertailua [Comparison of the authorised translator's examinations in force to date]. In T. Leblay (Ed.), Auktorisoidun kääntäjän tutkinnon historiaa ja nykypäivää [The Authorized Translator's Examination: Past and present] (pp. 26-34). Opetushallitus. Raportit ja selvitykset 2017:16. Helsinki: Finnish National Board of Education.

Salmi, L., \& Kinnunen, T. (2015). Training translators for accreditation in Finland. The Interpreter and Translator Trainer, 9(2), 229-242.

Salmi, L., \& Penttilä, A. (2013). The system of authorizing translators in Finland. In D. Tsagari \& R. van Deemter (Eds.), Assessment issues in language translation and interpreting (pp. 115-130). Frankfurt am Main: Peter Lang.

Taibi, M., \& Ozolins, U. (2016). Community translation. London: Bloomsbury.

TAUS (2016). Harmonized DQF-MQM error typology. Retrieved from https:/www.taus.net/evaluate/qt21-project\# harmonized-error-typology.

Turner, B., Lai, M., \& Huang, N. (2010). Error deduction and descriptors: A comparison of two methods of translation test assessment. Translation \& Interpreting: The International Journal for Translation \& Interpreting Research, 2(1), 11-23. 
ÜDPO = Prüfungsordnung für Übersetzer und Dolmetscher (2016). [Examination regulation for Translator and Interpreter] (2016, October 16). Retrieved from http://www.gesetze-bayern.de/Content/Document/BayUe DPO

\section{Appendix}

\begin{tabular}{|c|c|c|c|}
\hline $\begin{array}{l}\text { Scoring chart used by the assessors of the } \\
\text { Authorized Translator's Examination in } \\
2012-2014 \\
\text { Error category }\end{array}$ & Error type & & Points \\
\hline \multirow[t]{9}{*}{$\begin{array}{l}\text { Equivalence of content }(\mathrm{C}) \text {; precise and } \\
\text { faultless use of special terminology. }\end{array}$} & $\begin{array}{l}\text { An idea is completely misinterpreted } \\
\text { An entire sentence is left out }\end{array}$ & $\mathrm{C} 1$ & $9 \mathrm{p}$. leads to a failed examination \\
\hline & A wrong term leading to the misinterpretation of the translation & $\mathrm{C} 2$ & $9 \mathrm{p}$. leads to a failed examination \\
\hline & The translation function is disregarded, leading to an inadequate result & $\mathrm{C} 3$ & $6 \mathrm{p}$. may lead to a failed examination \\
\hline & $\begin{array}{l}\text { Unfounded alternative translation equivalents, i.e. the choice is left to } \\
\text { the evaluator }\end{array}$ & $\mathrm{C} 4$ & $6 \mathrm{p}$. may lead to a failed examination \\
\hline & $\begin{array}{l}\text { An omission or an addition essentially affecting the meaning of the text, } \\
\text { e.g. a general and crucial abbreviation is not translated }\end{array}$ & $\mathrm{C} 5$ & $\begin{array}{l}6-4 \text { p. depending on the severity of the } \\
\text { omission; } 6 \text { p. may lead to a failed } \\
\text { examination }\end{array}$ \\
\hline & Misinterpreted structure & C6 & $6-2 \mathrm{p}$. \\
\hline & $\begin{array}{l}\text { An individual word/term that is imprecise, unsuitable or irrelevant for } \\
\text { the content or culture but does not necessarily lead to the } \\
\text { misinterpretation of the translation } \\
\text { An omission or an addition not essentially affecting the meaning of the } \\
\text { text }\end{array}$ & C7 & $4-2 \mathrm{p}$ \\
\hline & $\begin{array}{l}\text { Incomplete or erroneous equivalents for the cultural and social context } \\
\text { of the source language }\end{array}$ & $\mathrm{C} 8$ & $2 \mathrm{p}$ \\
\hline & A structural error that is likely to cause misinterpretation & $\mathrm{A} 1$ & $\begin{array}{l}6-4 \text { p. depending on the severity of the } \\
\text { error; } 6 \text { p. may lead to a failed } \\
\text { examination }\end{array}$ \\
\hline \multirow{6}{*}{$\begin{array}{l}\text { Acceptability and readability of text (A). } \\
\text { General acceptability and readability of } \\
\text { text; usage according to orthographical, } \\
\text { morphological and syntactic norms; } \\
\text { register and style correspond to the text } \\
\text { function and the intended use of the } \\
\text { translation. }\end{array}$} & Inconsistent terminology or style & A2 & $6-2 \mathrm{p}$. \\
\hline & A spelling mistake that affects the interpretation of the text section & $\mathrm{A} 3$ & $4-2 \mathrm{p}$ \\
\hline & Inadequate translation in terms of the information structure of the text & A4 & $2 \mathrm{p}$ \\
\hline & A structural error that does not cause misinterpretation & A5 & $2 \mathrm{p}$. \\
\hline & Individual style errors and unidiomatic expressions & A6 & $2-1 \mathrm{p}$. \\
\hline & $\begin{array}{l}\text { A spelling mistake that does not affect the interpretation of the text } \\
\text { section }\end{array}$ & A7 & $1 \mathrm{p}$ \\
\hline
\end{tabular}


1 The terminology used also varies: "certification", "accreditation" and "authorization" are all used, with slightly different meanings (see Melby, 2013; Hlavac, 2013; Pym et al., 2012, pp. 15-16, 25-26 for discussions on terminology). We use the term "authorization" to be in line with the Finnish system (see FNBE, 2012).

2 This refers to the Finnish authority responsible for developing education, training and lifelong learning, and for promoting internationalisation. The official English translation of their name changed in 2017 to the Finnish National Agency for Education, but here we use the earlier translation as the vast majority of our sources date from 2016 or before.

3 In 2012-2014, there were eight C errors and seven A errors (see Appendix); the scoring chart in use since 2015 contains seven $C$ errors.

4 The Authorized Translators' Board granted us permission to do this research at its meeting on 14 December 2015. 